\title{
NEED ANALYSIS IN LEARNING ENGLISH FOR NON ENGLISH PROGRAM AT TARBIYAH AND TEACHER TRAINNING FACULTY
}

\author{
Yuwin R. Saleh \\ yuwinsaleh@iaingorontalo.ac.id \\ (Dosen IAIN Sultan Amai Gorontalo)
}

\begin{abstract}
This research aims to obtain information about the needs of learners in Englih learning especially non English department students surroundings of Tarbiyah and teacher training Faculty of IAIN Sultan Amai Gorontalo, the results of the analysis of data obtained via the questionaire form as the main instrument. Based on the data analysis, it was obtained information that the English material should be submitted by using the strategies varied, English has four skills with more emphasized on a competency-based vocabulary, this is because learners expected through vocabulary they can understand a textbook material on other subjects which is very useful for them in job field.

Penelitian ini bertujuan untuk memperoleh informasi tentang kebutuhan peserta didik dalam belajar bahasa Inggris khususnya peserta didik non program studi Pendidikan Bahasa Inggris dilingkungan Fakultas Ilmu Tarbiyah Dan Keguruan IAIN Sultan Amai Gorontalo, hasil analisis data yang didapat melalui angket sebagai instrument utama diperoleh informasi bahwa materi Bahasa inggris hendaknya disampaiakn dengan menggunakan strategi yang bervariasi, materi Bahasa Inggris meliputi empat ketrampilan dengan lebih memberi bobot pada kosa kata berbasis kompetensi, hal ini dikarenakan peserta didik mengharapkan dengan kosa kata tersebut mereka bisa memahami materi materi buku teks pada mata kuliah lainnya yang berbasis kompetensi juga bisa menjadi bekal mereka dalam dunia kerja nanti
\end{abstract}

Keywords: Need analysis, Learning English, Non English Department 


\section{A. Introduction}

The history of English empire has contributed significantly to the spread of English worldwide, geographically and culturally. Geohistorically, English has spread in three ways such as inner circle refers to nations using the language as their mother tongue, in example US, Canada, Australia, and New Zealand. The "outer circle" includes those are from some 55 ex British colonial countries, where English may be the language of the court, the medium of instruction at least in some levels of education, the press, or the government and is usually the official language, the third is expanding circle ; it is includes the nations that recognize the importance of English as an international language, included studying and history of nations.

In addition, the global status of English cannot be separated from its other popular role as the language of science and technology. Advancements in sciences and technologies that relate to a wide range of human needs including the press, transportation and communication in research, experiments and inventions have been report as knowledge. The continuous advancement of commerce and technology has created the need for students and professionals to master the language of commerce and technology not only for academic purposes but also for occupational purposes. The role of English in commerce and technology has been widely recognized and English courses which cater for this need have been and will continue to play a significant role in the development of commerce and technology. Unlike English courses for general purposes, English for specific purposes is different in the way the course is designed.

In Indonesia, although English is not as widely and accurately use as native speakers naturally, the language is relatively ubiquitous and it is use actively in some cases. At least two English newspaper ( i.e the Jakarta Post and the Indonesia Observer) are nationally distributed. Five national television and many radio stations broadcast a version of their news or current affairs in English once daily in the morning or evening, In addition to their entertainment programs involve songs and movies in English. In cities, it is common to see and meet English speaking tourists, these are the mirrors of the using English as global status in the world. Therefore in Indonesia, English is one of the most important subjects in which it has been teach in every stage of education, include Islamic Higher Education.

It has been generally accepted that the success of language teaching program depend on some important aspects such as teacher competent, curriculum and students readiness toward 
learning and teaching material. The role of teaching materials has been recognized for decades. Renandya argue that teaching material is a key component in most language program. They said that whether the teacher uses textbook, institutionally prepared materials or make use of his own materials instructional materials serve as the basis for much of the language input learners receive and the language practice that occurs in classroom ( $\mathrm{J}$. C.,Renandya, W, 2002: 65)

A good and competent teacher is encouraged to make his/her own instructional materials to fit the need of their learner. However, in developing or designing his/her own materials there are some factors that the teacher should pay attention to. In developing teaching materials a teacher, according to McDonough \& Shaw should be guided by syllabus, syllabus is derived from the goals which want to be achieved in the language program. The goals are formed by the nature context of the language teaching program which are the learners themselves and the educational setting where the teaching will occur (McDonough, J. \& Shaw, C, 2003: 4).

By considering the idea of McDonough \& Shaw above it is clear that the analysis on the context, that is where and who the learners will be, is very crucial in developing teaching material. The writing of instructional materials used in IAIN Sultan Amai, an Islamic college operating in Gorontalo Province, needs to be increased in anticipation of the growing number of students studying there and need to suit the teaching material with the needs of the students like Mukhtar said that in the Islamic hgher education level, learning transformation might be contributed and provided the aims of teaching and learning process of high education clearly, it should be suitable with students' need, it means that in arrange the materials it should be better based on the students' need include in arrange English materials (Carter Ronal \& Nunan,David, 2002 : 131).

As the one of subject, English materials at IAIN Sultan Amai Gorontalo should be based on the students neecd. In this framework of thinking the English taught in IAIN can be called English for special Purposes (ESP). According to Evans (Carter \&Nunan) the key defining feature of English for Special Purposes is that the teaching and materials are founded on the results of need analysis. He says that in developing a material for ESP the teacher should be guided by the questions: "what do the students need to do with English?, which of the skills do they need to master and how well and which genre do they need to master?"( Wello, B. \& Nur. H. A. J, 2008: 6). 
With regard of the guidelines by Evans above the English taught in IAIN should be English for Special Purposes (ESP), in this case The English for Specific Purposes should based on the faculty competence. In support with this claim is what Wello and Nur claim that absolute characteristics of ESP are: "designed to meet specific need of the learner, related in content to particular discipline, occupation and activities also centered on the language appropriate to those activities in syntax, lexis, discourse, semantics and need analysis".

IAIN sultan Amai Gorontalo has four faculties namely Tarbiyah and Teacher Training Faculty, Tarbiyah and Teacher Training Faculty, Ushuluddin Faculty and Bussiness and Economic faculty. It means that it should be better in English teaching learning and process, the English materials based on the ESP.

Based on the researcher's pre observation, especially in Tarbiyah and Teacher Training Faculty, it is found that English subject has been taught at the first semester, the English lecturers use available book as their handbook in teaching and learning process. Based on the interview, they said that they have difficulties to find out the book that related with the faculty competence. This fact encourages the researchers to make a research to find out how are students' needs in learning English, the researches formulating it in the title "Analysis students' Need In Learning English For non English Program At Tarbiyah And Teacher Training Faculty". The research question in this research is how are the students' In learning English for non English program at Tarbiyah And Teacher Training Faculty?

\section{B. Literature Review}

\section{English Specific Purpose (ESP)}

In the first phase of ESP history, (the 1960S and the early 1970S), ESP researchers and teachers concentrated on the sentence-level characteristics of the types of English identified as useful to their students. They discovered, among many others things, that English of Science and Technology (EST) favors the present simple tense, the passive, and noun compounds ; they also discovered that business letters contain a set formal, many formulaic expressions, a limited vocabulary, and a limited set of conjunctions. After careful analysis of identified spoken or written discourse, practitioners organize their grammar based curricula around the features of these social registers. 
In the second phase of ESP (late 1970S and early 1980S), have modernizing influences on register analysis, such as those which integrate grammatical form with rhetorical functions (relatively frequent use of "passive" in EST as compared to GE), in this phase the focus of register analysis became more rhetorical.

In the third phase the researches concentrated upon systematic analysis of the target situation in which students are found to be employing spoken English, in an attempt to make a notional functional curriculum to central focus namely the communicative purpose of a speaker/writer, the setting of language use and the mode of communication and language use.

Recently, the fourth phase, rather than centering on the discourse, the communicative situation or the learners' communicative process, the focus is upon the strategies which learners employ to acquire the target language and emphasis need assessment.

From historical description about ESP above it is clear that ESP concentrates more on language in context than on teaching grammar and language structures. The ESP vocal point is that English is not taught as a subject separated from the students' real world (or wishes); instead, it is integrated into a subject matter area important to the learners. In ESP it is a need analysis that determines which language skills are most needed by the learners and the syllabus is designed accordingly, in this matter ESP can be say that ESP have highly motivating the learners because the learners are able to apply what they learn in their English class to their main field of study, they are able to use the vocabulary and structures that they learn in meaningful context.

The term "specific" in ESP refers to the specific purpose for learning English. The learners approach the study of English through a field that is already know and relevant to them. This means that the learners are able to use what they learn in ESP classroom right away in their work and studies. The ESP approach enhances the relevance of what the learners are learning and enables them to use the English they know to learn even more English, since their interest in their field will motivate them to interact with speakers and texts.

Robinson writes" During the period of roughly ten years a wealth of terms has grown up. LSP (language for Special Purpose) is the International terms and although most of work on languages for special purposes has been on the English language, a consideration of some LSP research provides a useful insight into some shortcomings and preoccupations (Robinson. P. C, 1984 : 5)". 
This allegation of Robinson above shows that English for Special Purpose is one of international terms referring to the kind of language learned by learners to achieve certain purpose. Apart from English, there are many other languages learnt for special purposes.

Streven (Wello\&Nur) propose two categories on ESP. The first is absolute categories and the second is variable categories. Absolute categories include it is designed to meet specific needs of the learners, It is related in content to particular discipline and it is centered on the language appropriate to those activities in syntax, lexis, discourse and analysis of this discourse (Wello, B. \& Dollah S, 2008 : 14).

It is obvious that by referring to the idea of Robinson and Strevens above the English taught in Islamic colleges should be called English for Special Purpose. Point three by Robinson clearly says that one the characteristic of ESP is that it is used for academic or professional study such as engineering, Islamic studies and so on. Similarly, point two of Strevens's idea says that ESP related in content to particular discipline.

Further Strevens (Wello \& Nur) said that "ESP may be, but not necessarily, restricted as to the language skills to be learned, e.g reading only not taught according to any pre-ordained methodology (Wello, B. \& Dollah S, 2008 : 14)”.

According to Wello \& Nur ESP can be subcategorized into English for Occupational Purpose (EOP) and English for Academic Purpose (EAP). EOP involves mostly work-related needs and training while EAP involves academic and study needs (Wello, B. \& Dollah S, $2008: 14)$.

To sum up, English taught in Islamic college can be categorized as English for Special Purpose. Hence, the materials to be developed for the teaching should be designed into English catering special purpose for students' in this case academic needs of students.

\section{Need Analysis}

ESP courses set out to teach the language and communication skills that specific groups of language learners need or will need to function effectively in their disciplines of study, professions or workplaces. Because ESP focuses on teaching specific language and communication skills, ESP course design usually includes a stage in which the course developers identify what specific language and skills the group of language learners will need. The identification of language and skills is used in determining and refining the content for the ESP course. It can also be used to assess learners and learning at the end of the course. This process is termed 'needs analysis'. 
Needs analysis in ESP refers to a course development process. In this process the language and skills that the learners will use in their target professional or vocational workplace or in their study areas are identified and considered in relation to the present state of knowledge of the learners, their perceptions of their needs and the practical possibilities and constraints of the teaching context. The information obtained from this process is used in determining and refining the content and method of the ESP course.

Wello and Dollah ( 2008 ; 65) stated that " need analysis or need assessment in a language program is often viewed simply as identification of the language forms that the students will likely need to use in the target language when they are required to actually understand and to produce the language (Wello, B. \& Dollah S, 2008 : 14) “.

The above theory means need analysis is to establishing the how and what of a course, it is a continuous process, since a materials developer modify his/her teaching as he/she come to learn more about his/her learners, and in this way it actually shades into evaluation - the means of establishing the effectiveness of a course. Needs is actually an umbrella term that embraces many aspects, incorporating learners' goals and backgrounds, their language proficiencies, their reasons for taking the course, their teaching and learning preferences, and the situations they will need to communicate in. Needs could involve what learners know, don't know or want to know, and can be collected and analyzed in a variety of ways.

Need analysis procedures may involve interviews with students to determine perceptions of their major language difficulties, interviews with lecturers and instructors, observation of students in class to observe how well they can carry their assignments, examination of their lecture notes, essays, and so on to determine their difficulties, as well as tests of different kinds to determine students level of proficiency in reading, writing and note taking. The aims of a need analysis are thus to determine the types of situational in which learners will be using English, the tasks and activities they are expected to carry out or take part in English and their existing language skills or abilities with respect to those tasks.

Practical guidelines to needs assessment is proposed by Isaac and Michael (in Wello and Dollah,) as follows :

a. Identity the students-oriented goals (needs are based on goals).

b. Rank the importance of these goals without regard to performance levels which are categorized as high, moderate, or low importance. 
c. Asses the level of performance for each of the goals. The performance level for each goal is categorized as high, moderate, or low

d. Establish a priority for each student's goal, considering both importance and performance (Wello, B. \& Dollah S, 2008 : 66).

In assessing need, in this research the researchers will use approach to need analysis is learning-centered approach that learning is totally determined by the learner. In this approach involve target needs (what the learner needs to do in the target situation) and learning needs ( what the learner needs to learn). For target needs Hutchinson and Waters consider that the information necessary for the course designer should be obtained by posing detailed questions :
a. Why is the language needed?
b. How will the language be used?
c. What will the content areas be?
d. Who will the learners use the language with?
e. Where will the language be used?
f. When will the language be used?

Similarly, they also pose questions to analyze learning needs :
a. Why are the learners taking the course?
b. How do the learners learn?
c. What resources are available?
d. Who are the learners?
e. Where will the ESP course take place?
f. When will the ESP course take place? (Hutchinson Tom \& Waters Alan, 1990:59)

\section{Research Method}

This research is designed as in qualitative method. According to Creswell qualitative procedures demonstrate different approach to scientific inquiry than quantitative research method. Its inquiry occupate different assumption philosophically such as: strategies of inquiry; methods of data collection, analysis, and interpretation. The participants were the students of Tarbiyah And Teacher Training Faculty, they were one hundred students from PAI, MPI, PIAUD, PGMI and PBA program which twenty students for each program. They answered the questioner as main instrument in this research that covered items of : 
1. The students' need in English learning

2. The students' reasons to learn English

3. The students' preference in English be used

4. The students' preference for the teacher way in teaching English

5. The students' preference in learning reading text

6. The students' preference the content of English materials

7. The students' preference to use English language with ?

8. The students' area in the language be used?

9. The students' preference about the time to study English

10. The students' way to learn English

11. The students' preference to do homework

12. The students' preference to spend the time

13. The students' preference to learning English from?

14. The students' preference about useful activities in learning English

\section{Findings and Discussion}

Based on the analysis the data, I found that the students' needs in learning English for reading literature, it supported by the students' first priority to the question number 1 , in which they chosen for reading literature was $40 \%$, the students' answer to question number 2 about the students' reason in learning English, in which for the question their first priority was to find specific vocabularies with scores $49 \%$.

For students preference in English be used, the students chosen to understanding the literature was $40 \%$ this was first priority, the students' preference for the teacher way in teaching English, the students chosen use variety of strategic as their first priority, it was $40 \%$, The students' preference in learning reading text, their score was $42 \%$ for reading text based on the competence as first priority, The students' preference the content of English materials, they chosen covers four skills namely, writing, reading, listening, and speaking, and it was completed with exercises that the students have to do whether in class or in their house as homework, whether in individually task or group, as their first priory with score $42 \%$. 
to presenting the material, the English lecturer used face to face technique in big group, for the students who have difficulties in understanding the material, the lecturer gave the remedial in small group, this is to respect the students preferences about learning English style, in which in this case their first priority in big group by guiding the lecturer in $72 \%$ and second priority in small group was $68 \%$. The time used to teach the material at once in a week in $2 \frac{1}{2}$ hours.

In presenting the materials, the English lecturer has to use English and Indonesian language sometimes use verbal language to make students more understood to the material, this is to recommended the students' preferences about the English lecturer method in teaching the material, in which in this question their first priority was English and Indonesia also verbal in $51 \%$ scores.

In teaching and learning process to make the English lecturer easy in presenting the materials, it should be better if the English lecturer used handbook for her/himself also gave the students book package so the students have direction about the material that they have to study .

For reading material of this products, the English lecturers should prepared reading materials based on the Faculty, in this case like a text of short reading, this based on the students preferences toward reading materials, in which in this case, their priority was reading based on the Faculty in a short text form as first priority and the English lecturer can use reading comprehension technique.

To improve students speaking ability, the material used retelling technique, in this case retell about the content of reading text, this is to fulfill the students responses through question number 14 about their preferences toward method in teaching speaking, in which in this case their first priority was retell in 51\% scores, also sometimes English lecturer may ask students to read the text of reading as their second priority.

For writing skill, to improve students writing skill, the English lecturers must give their focus in using grammar exercise like ask students to make sentence toward grammar in focus, ask students to make conclusion about the content of reading or about something through audio visual. In improving students listening skill, in the material prepared dictation method by English lecturer whether in classroom or in language laboratory. 


\section{E. Conclusions}

Based on the data analysis, it is clear that the students' needs in studying English for reading literature completed with specific vocabularies, because by knowing and using specific vocabularies, it can help the students to understand their text book, this is suitable with the students' answer to question number 2 about their priority in learning English, in which for the question their first priority was to find specific vocabularies with scores $49 \%$.

The English material should involves four skills namely, writing, reading, listening, and speaking, and it was completed with exercises that the students have to do whether in class or in their house as homework, whether in individually task or group, to presenting the material, the English lecturer used face to face technique in bog group, for the students who have difficulties in understanding the material, the lecturer gave the remedial in small group, this is to respect the students preferences about learning English style, in which in this case their first priority in big group by guiding the lecturer in $72 \%$ and second priority in small group was $68 \%$. The time used to teach the material at once in a week in $1 / 2_{2}$ hours.

In presenting the materials, the English lecturer has to use English and Indonesian language sometimes use verbal language to make students more understood to the material, this is to recommended the students' preferences about the English lecturer method in teaching the material, in which in this question their first priority was English and Indonesia also verbal in $51 \%$ scores.

In teaching and learning process to make the English lecturer easy in presenting the materials, it should be better if the English lecturer used handbook for her/himself also gave the students book package so the students have direction about the material that they have to study in a semester, but in this research, I did not make book package for the students, it depend on the English lecturer who will use this materials to make book package based on his/her creativity.

For reading material should be based on the Faculty, in this case like a text of short reading, this based on the students preferences toward reading materials, in which in this case, their priority was reading based on the Faculty in a short text form as first priority and the English lecturer can use reading comprehension technique.

To improve students speaking ability, the material used retelling technique, in this case retell about the content of reading text, this is to fulfill the students responses through question number 14 about their preferences toward method in teaching speaking, in which in 
this case their first priority was retell in 51\% scores, also sometimes English lecturer may ask students to read the text of reading as their second priority.

For writing skill, to improve students writing skill, in the material of this exercise also ask students to make sentence toward grammar in focus, ask students to make conclusion about the content of reading or about something through audio visual. In improving students listening skill, in the material prepared dictation method by English lecturer whether in classroom or in language laboratory. 


\section{REFERENCES}

Crawford, J. (2002) How Authentic is the Language in Our Classroom? Prospect 6(1) 47- 54

Carter Ronal \& Nunan,David (2002) Teaching English to Speakers of Other Language. Cambridge : University Press

Hutchinson Tom \& Waters Alan. (1990). English For Specific Purposes. A learning-centred approach. Cambridge : University Press

McDonough, J. \& Shaw, C.(2003). Materials and Methods in ELT. Blackwell Publishing.

Robinson. P. C, (1984). English for Special Purpose. Pergamon Press. Oxford

J. C.,Renandya, W. (2002) Methodology in Language Teaching: an Anthology of Current Practice.Cambridge University Press

Tomlinson.B., (2003). Developing Materials For Language Teaching. Continuum. New York

Tomlinson (2003) Developing Language Course Materials. Seameo Regional Language Centre. Singapore

Wello, B. \& Nur. H. A. J,(2008). An Introduction to ESP. Badan Penerbit Universitas Makassar

Wello, B. \& Dollah S. (2008) Fundamental Aspect of English for Special Purpose. Badan PenerbitUniversitas Makassar. 